\title{
A afinação de coro no Teatro Oficina
}

\section{The tuning of the choir in Teatro Oficina}

\section{Letícia Coura}

Letícia Coura

Letícia Coura é artista, atuando como cantora, compositora, atriz e preparadora vocal. Mestre em Artes Cênicas pelo PPG-AC da USP.

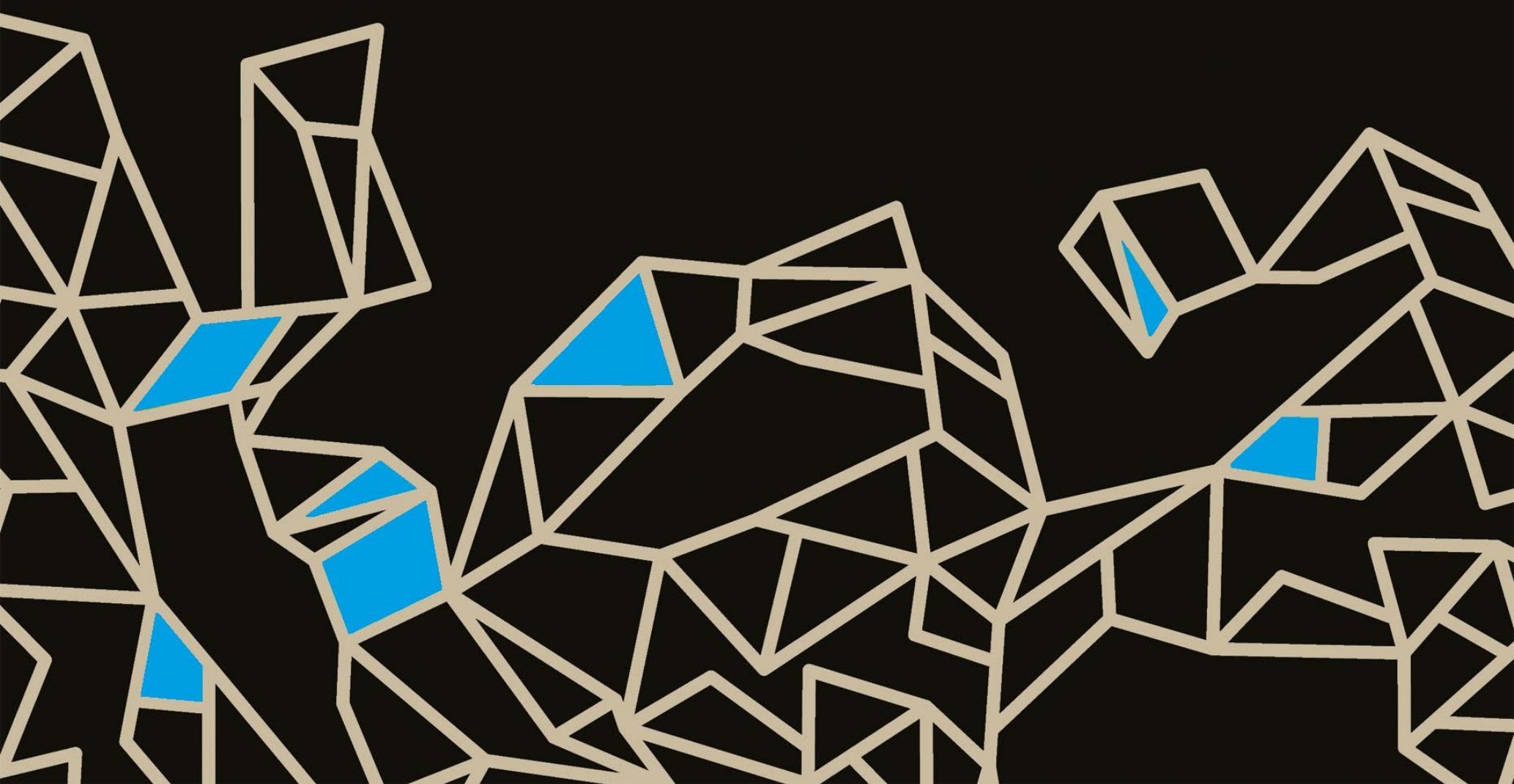


Se eu tivesse que escolher apenas um dentre os grandes aprendizados dos anos que passei no Teatro Oficina, sem dúvida um forte concorrente seria a consciência de que um espetáculo - e isso vale para qualquer outra "obra" de arte - nunca está pronto. Que ele pode - e vai - sempre mudar.

Só não esperava que isso fosse valer para a música também. Canções. Uma canção nunca está engessada. Ela pode mudar sempre. Mesmo uma canção de outro compositor, mesmo canções já gravadas, mesmo criações de compositores consagrados como Chico Buarque, Caetano Veloso, Paul Hindemith ou Villa-Lobos. Tudo pode ser antropofagiado naqueles ensaios de dez, doze, quinze horas de duração. Se for para melhor contracenar com a dramaturgia, dialogar com ela, elucidá-la, enriquecê-la, ultrapassá-la, nada estará pronto. Tudo pode - e vai - mudar.

O problema é trazer essa prática para a música. Para uma canção a ser cantada por um coro de atores, geralmente bastante heterogêneo em sua relação e prática com a música. Penamos a aprender uma passagem de uma composição de Paul Hindemith para o espetáculo Acordes, de Bertolt Brecht $^{1}$, para muitas vozes, com intervalos difíceis de cantar até para um cantor lírico experiente. Aí chega o diretor, não gosta da nossa interpretação, "muito dura”, e resolve mudar o ritmo da música, experimentar outro gênero, mudar o andamento. Ou começa a primavera, e o diretor - que muitas vezes é também o dramaturgo - resolve acrescentar alguns versos a alguma canção do repertório aprendido a duras penas por todos, mudando a melodia, trocando a harmonia para melhor adequá-la ao que o novo texto está pedindo. Isso a alguns minutos de dizermos o MERDA! e abrirmos as portas do teatro para o público entrar.

E o que num primeiro momento parecia impossível de se fazer - mudar uma melodia já existente, ou já criada e ensaiada - é feito. Muda-se a melodia, ou a letra, ou a harmonia, ou tudo junto, e naquele dia o espetáculo, mais uma vez, não poderá ser feito no automático, teremos que estar totalmente presentes e ligados na música e uns nos outros, para conseguirmos cantar a nova versão da música, com a nova intenção proposta pelo diretor. E juntos, em coro. Temos com isso um coro sempre ligado no aqui agora, na interpretação

1 Dirigido por José Celso Martinez Corrêa nas temporadas de 2012 e 2013 do Teatro Oficina. 
de hoje, para o público que foi hoje ao teatro, e merece a melhor atuação de todos os tempos. $E$ todo dia tem que ser assim.

Fui parar no Oficina para trabalhar o coro do espetáculo Bacantes, de Eurípedes, em 1999, com direção de Zé Celso. Na época o Zéz queria alguém que trabalhasse a música da peça com o coro, alguém que aprendesse todas as canções, pudesse e tivesse a vontade - e a paciência - de passar para e com todos. Teríamos pouco tempo de ensaio - depois entendi que quase sempre seria assim -, e o Zé queria conseguir afinar um pouco o coro. Naquele momento ainda nem sabíamos quem faria parte dele. Provavelmente a maioria dos integrantes não conheceria o repertório, e grande parte deles não seria muito familiarizada com o universo musical.

Naquele momento - de Bacantes de 1999 para o de 2000 - o objetivo era afinar, mesmo que minimamente, o coro. Anos - e muitos espetáculos depois ouvi do mesmo Zé que o coro estava soando afinado demais, "classe média", que estava careta. Entendi que o coro poderia estar soando um pouco uniforme demais, com pouca interpretação, meio chapado, sem nuances rítmicas. Sem nuances de timbre. Seriam os arranjos vocais? Os arranjos da banda? Cansaço de uma mesma fórmula repetida muitas vezes? Cansaço dos nossos próprios timbres? Uma mistura de tudo isso?

\section{O ator cantor e/ou vice-versa}

Para o Zé (e para quem não?), o ator tem que interpretar o que canta. Saber o que diz. Sempre me impressionei com atores que cantam. E cantores que realmente interpretam o que diz a letra. Um problema que tínhamos sempre nos ensaios de música do teatro era a impaciência do diretor para o aprendizado de uma canção. Saber a melodia. Saber ouvir a harmonia.

Sob o ponto de vista (e de escuta) de um músico, a melodia é como o texto para o ator. Quantas vezes ensaiamos um ator cantando uma canção, e a atenção e o tempo dados ao texto não eram dados também à música, à compreensão, à sua absorção, à escuta da harmonia. E aprendizado também

2 José Celso Martinez Corrêa, diretor fundador do Teatro Oficina; durante este artigo, quase sempre quando me referir a ele será como Zé, do mesmo modo como ele é chamado nos ensaios. 
da melodia, sem tabu com o verbo aprender. Mas para o Zé - que é um ótimo cantor e compositor, toca piano, tem facilidade de improvisar dentro da harmonia, mas não tem a mesma relação tranquila com os músicos em relação ao ritmo, porque está muito mais ligado no ritmo da cena, que muitas vezes não coincide com o ritmo pedido pela banda -, a música tem que ser intuitiva, "brotar do ator", deve servir à compreensão do texto. Deve desvendá-lo.

Passados alguns anos de parceria, chegamos num embate em relação ao trabalho com o coro. Durante todo o processo d'Os Sertões ${ }^{3}$ de que participei, de 2002 a 2007, e que considero a gênese de um processo meu com o coro do Teatro Oficina já experimentado nos processos anteriores para gravação dos DVDs dos espetáculos Bacantes e Ham-Let em 2001, o trabalho com a voz juntamente com o de percepção musical do coro casou perfeitamente com as aspirações do diretor em relação à qualidade musical do coro. Conseguimos dar um salto na questão básica da afinação geral do elenco e chegamos a bons resultados no que diz respeito ao ritmo e a uma percepção maior da harmonia. Chegamos mesmo a compor muitas canções em grupos grandes, o que talvez tenha sido a nossa maior e mais original conquista, uma raridade pela dificuldade em reunir tantos elementos com uma disponibilidade inventiva e interpretativa, de escuta, de tentativa e erro. Horas em cima de uma canção, Zé dando direções de interpretação, ampliando conteúdos, caminhos para a composição, um ou mais músicos e muitos atores juntos, com diferentes níveis de familiaridade com a música e diferentes influências, compondo em coro uma mesma canção. Cada um improvisando a partir de seu universo musical, dialogando com referências musicais completamente distintas, e criando a partir desse encontro composições originais, estranhas, fáceis, difíceis, gostosas de cantar, ou nem tanto, mas principalmente canções que dialogavam diretamente com os atores, que se reconheciam nelas.

3 Os Sertões, adaptação do clássico de Euclides da Cunha pelo Oficina, de 2000 a 2007, resultando em cinco espetáculos: A Terra, O Homem I - do nascimento à revolta, O Homem IIda revolta ao trans-homem, $A$ Luta I - $1^{\text {a }}$. $2^{\mathrm{a}}$. e $3^{\mathrm{a}}$. Expedições, e A Luta II - o desmassacre, com apresentações no Teatro Oficina em São Paulo, turnês por Canudos (BA), Quixeramobim (CE), Recife (PE), Salvador (BA), Berlim, Alemanha, e participações nos festivais EnCena no Rio de Janeiro, NO FEAR em Recklinghausen, Alemanha, e São José do Rio Preto (SP). As pouco mais de 26 horas dos espetáculos d'Os Sertões pelo Teatro Oficina estão disponíveis online, no canal de YouTube TV Uzyna com legendas em português e inglês. Disponível em: https://bit.ly/3ar42vJ. Acesso em: 2 fev. 2021. 
Dando um salto no tempo, já depois de outras criações e espetáculos, ouvi do diretor que o coro estava soando afinado demais. Como uma crítica. "Afinado demais, careta demais, classe média demais". Tirando todas as implicações particulares e circunstanciais da questão, esse embate me fez pensar, me questionar, e me instigou a aprofundar a minha percepção do que era a música no teatro, especificamente no Teatro Oficina e nas nossas criações. Quanto mais fundo chegava nas minhas reflexões, mais parecia concordar e discordar ao mesmo tempo do diretor.

Toda a minha defesa da música como fator determinante para atingirmos esse grau dionisíaco - buscado incansavelmente no Oficina - referia-se a esse lugar da música um pouco além da compreensão cognitiva.

A palavra age primeiramente sobre o mundo dos conceitos e somente a partir daí sobre o sentimento; e de maneira bastante frequente ela não alcança absolutamente, pela distância do caminho, o seu alvo. A música, por outro lado, toca o coração imediatamente, como a verdadeira linguagem universal, inteligível por toda parte (NIETZSCHE, 2005a, p. 65-66).

Cada vez mais eu estava encontrando resistência no diretor aos aquecimentos de voz voltados à afinação do coro, a uma maior qualidade na percepção musical dos atores, a uma maior familiaridade com a linguagem musical, necessários para o desenvolvimento de uma maior liberdade em sua relação com a música. Estávamos a cada nova montagem - com diferentes diretores musicais - enfrentando desafios musicais maiores, divisão de vozes, harmonias sofisticadas. E o Zé insistindo que a palavra era o mais importante, o sentido do que se cantava, e não a música propriamente dita, não a melodia exata, as notas "certas.' E agora, José? Como prosseguir?

Para falar do ator cantor, ou cantor ator, vamos unir conceitos que não estão - ou ao menos não deveriam estar - separados. Como separar o teatro da música, a música da dança, a dança da cenografia, a cenografia das artes plásticas, as artes plásticas das artes visuais, e tudo isso da tecnologia, das novas linguagens que vão se criando e se modificando a cada dia? Mas vivemos essa separação, talvez pela imposição de um mercado das artes, do show business, para orientação do público, dos patrocinadores ou dos guias de cultura que vão se extinguindo e virando propaganda de entretenimento. 
O que acontece na prática é que tudo se mistura, a arte total, já presente em tantas culturas com seus diversos ritos; a esse respeito, nossos povos originários têm muito a nos ensinar sobre sua relação singular com a arte, que muitos nem a denominam desse modo. Sem o conceito de arte, a vida é toda arte, sagra-se tudo, qualquer fenômeno, ação ou objeto, tudo é sagrado e parte do tudão.

Mas, voltando ao ator cantor e vice-versa. Fui parar no teatro por causa da música, e na música sempre me considerei de teatro. Um sem o outro não existe. Um intérprete - como o nome já diz - que não interpreta, que não atua, não será um cantor, e um ator que não canta - se não música, mas que não consiga fazer do texto música - será ator?

Porém, na prática, como unir as duas linguagens? Temos exemplos na Música Popular Brasileira de grandes cantores intérpretes que navegaram bem em águas distintas: Carmen Miranda na música, no Teatro de Revista e no cinema; Elis Regina com seus shows teatrais; a atriz Marília Pêra com seus espetáculos musicais; Elba Ramalho no teatro e no cinema; Vicente Celestino e Grande Otelo no circo e no cinema - para ficar apenas nos já considerados clássicos.

\section{Apolo \& Dionísio}

Normalmente vemos as divindades gregas Apolo representando a música e Dionísio, o teatro. Já que estamos unindo teatro e música, o mais óbvio então é juntar os dois. Mesmo porque, quando se fala nos rituais dionisíacos, a música está sempre presente. Há uma certa ordem na música sob a ótica apolínea que é necessária quando levamos a música para o teatro. Precisamos, então, entender a música a partir de uma linguagem matemática, pensando numa certa exatidão, para conseguirmos cantar em coro e junto com uma banda ao vivo, que, ainda por cima, toca instrumentos de harmonia temperados ${ }^{4}$, o que já é outro assunto.

4 O "temperamento igual" é uma forma europeia criada artificialmente para possibilitar uma padronização de afinação de instrumentos musicais e que resultou na utilização da harmonia como a conhecemos hoje, a partir de uma "ajeitada" na afinação natural, e à qual nossos ouvidos já estão acostumados, mas que não corresponde exatamente ao que poderíamos entender como harmonia genuína, pensando na física do som. Não terei como desenvolver esse assunto aqui, o que não tira sua relevância para um maior aprofundamento dessa questão a que chegamos, de uma possível música intuitiva, que seria mais próxima a uma ideia de uma música de pulsão dionisíaca. 
O músico Murray Schafer, no seu livro The Soundscape (1994), nos dá a seguinte definição da relação das duas divindades gregas com a música:

No mito dionisíaco, a música é concebida como som saindo do peito humano; no apolíneo é o som externo, mandado por Deus para nos lembrar da harmonia do universo. Na visão apolínea a música é exata, serena, matemática, associada a visões transcendentais da Utopia e da Harmonia das Esferas. É também a anãhata dos teóricos indianos. É a base das especulações pitagóricas e aquelas dos teóricos medievais (na qual a música era ensinada como parte do quadrivium, ao lado da aritmética, geometria e astronomia), assim como o método de composição das doze notas de Schoenberg. Seus métodos de exposição são teorias dos números. Procura harmonizar o mundo através de um desenho acústico. $\mathrm{Na}$ visão dionisíaca música é irracional e subjetiva. Emprega expressivos dispositivos: flutuações de tempo, sombreamentos de dinâmica, coloridos tonais. É a música da cena da ópera, do bel canto, e sua voz magra e aguda pode também ser ouvida nas Paixões de Bach. Acima de tudo, é a expressão musical do artista romântico, prevalecendo ao longo do século XIX e até o expressionismo do século XX. Também dirige a prática do músico atual. (SCHAFER, 1994, p. 6, tradução nossa) ${ }^{5}$

Mas a cada nova tentativa de entender um possível embate com o diretor na forma de trabalhar o coro, sentia um pouco inútil, ou no mínimo aquém do satisfatório, ir buscar numa abordagem teórica da dicotomia entre Apolo e Dionísio a chave de uma possível explicação para as nossas dificuldades com (e divergências quanto à maneira de trabalhar) o coro a partir das características e diferenças das duas divindades gregas, em sua relação com a música. Nossas dificuldades aconteciam num nível muito prático, de busca de

5 No original: "In the Dionysian myth, music is conceived as internal sound breaking forth from the human breast; in the Apollonian it is external sound, God-sent to remind us of the harmony of the universe. In the Apollonian view music is exact, serene, mathematical, associated with transcendental visions of Utopia and the Harmony of the Spheres. It is also the anãhata of Indian theorists. It is the basis of Pythagoras's speculations and those of the medieval theoreticians (where music was taught as a subject of the quadrivium, along with arithmetic, geometry and astronomy), as well as of Schoenberg's twelve-note method of composition. Its methods of exposition are number theories. It seeks to harmonize the world through acoustic design. In the Dionysian view music is irrational and subjective. It employs expressive devices: tempo fluctuations, dynamic shadings, tonal colorings. It is the music of the operatic stage, of bel canto, and its reedy voice can also be heard in Bach's Passions. Above all, it is the musical expression of the romantic artist, prevailing throughout the nineteenth century and on into the expressionism of the twentieth century. It also directs the training of the musician today." (SCHAFER, 1994, p.6) 
resultados concretos. Não estávamos divergindo estética nem teoricamente. Não era um debate de uma ideia acerca do coro, e sim das práticas diárias e dos resultados obtidos. Formas de ouvir.

A explicação que mais ilustra a diferença entre Apolo e Dionísio no que se refere à atuação do coro como entendi que era a nossa busca no Oficina a partir das direções do Zé - e que não está tratando exatamente da música -, fui encontrar n'O Nascimento da Tragédia de Nietzsche (2007), não sem uma ponta de misoginia, mas que como imagem é bem clara:

O ditirambo distingue-se de qualquer outro canto coral. As virgens que, com ramos de loureiro na mão, se dirigem solenemente ao templo de Apolo e, no ensejo, entoam cânticos processionários, continuam sendo o que são e conservam os seus nomes civis; o coro ditirâmbico é um coro de transformados, para quem o passado civil, a posição social estão inteiramente esquecidos; tornaram-se os servidores intemporais de seu deus, vivendo fora do tempo e fora de todas as esferas sociais (NIETZSCHE, 2007, p. 57).

Mas a nossa questão prática, o nosso maior desafio em relação à música, a partir da minha escuta, não era ser ou não ser dionisíaco ou apolíneo. A busca não era teórica. Nem estética. Era simplesmente (e que longo caminho até chegar ao que é mais simples) conseguir cantar junto para tornar palavras compreensíveis ao público. E, então, era como preparar um coro para conseguir cantar junto algumas canções a serem acompanhadas por um arranjo musical contendo certa harmonia - e suas regras como as conhecemos e seguimos hoje -, ritmo marcado e instrumentos temperados.

Ao final da tragédia Bacantes, na montagem do Teatro Oficina, Apolo e Dionísio se reencontram no Olimpo e reinam juntos e felizes. No dia a dia do teatro, talvez eles estejam em constante embate, o que só torna a busca estética mais instigante. Talvez sejam dois caminhos que levem ao mesmo lugar. O interessante aqui é justamente refletir a partir da prática, e como conseguimos fazer dialogar essas duas linguagens.

O grande desafio é um ator cantar em coro, seguindo apenas sua pulsão dionisíaca, e conseguir contracenar na mesma linguagem com a banda, que tem uma familiaridade com a música que poucos de nós ali do elenco tínhamos durante o processo d'Os Sertões. A saída foi tentar preparar 
musicalmente o grupo, praticar incansavelmente, diariamente, exercícios que nos colocassem minimamente em uma mesma sintonia fina com a música, para assim conseguirmos cantar juntos no mesmo ritmo uma mesma melodia, acompanhados por uma banda, com entradas e saídas para soarem em coro. Essas eram as condições essenciais para fazer compreensíveis as palavras cantadas - implícito aqui que os atores já teriam estudado o texto e conheciam o conteúdo do que seria cantado.

Temos exemplos de culturas muito antigas que têm na música cantada em coro sua forma principal de contato com o mistério. Realizam seus ritos através da música, com canto e dança. Faz parte da cultura a prática de cantar junto, e todos estão familiarizados a isso desde criança. Vão conhecendo as cantigas de tanto ouvir cantar os mais velhos e cantar junto. Não é o nosso caso no teatro. Parte do elenco já está agora acostumada a cantar junto como coro por ter participado de vários espetáculos da companhia, contracenando repetidas vezes com as mesmas pessoas. Mas, sempre tem gente nova chegando, cada um com uma história particular de contato com a música. E estamos fazendo espetáculos, mesmo que sejam espetáculos que se aproximem da linguagem ritual. O público comparece para assistir - ou ao menos é o que eles pensam que vão fazer.

Digo isso porque para cantar em coro pensando no espetáculo, na apresentação, a própria linguagem exige uma preparação dos atuadores para cantar uma mesma melodia, saber usar as próprias vozes, conseguir ouvir a harmonia, saber o que é que se vai cantar. Com os ensaios diários e uma prática musical constante, conseguimos um nível básico de afinação e, com o tempo, uma crescente capacidade de cantar dividindo vozes. Mas, pela falta da prática musical na nossa educação formal, e por muitos de nós não virmos de costumes e tradições nos quais se cultiva o hábito de cantar com frequência, normalmente temos um bom caminho a percorrer até conseguirmos cantar em coro, minimamente afinados, no mesmo ritmo, acertando as entradas e saídas das vozes.

Como conseguir uma qualidade musical digna de um espetáculo a ser apresentado, e que ao mesmo tempo não soe careta, afinado demais, "classe média demais"? Esse é o desafio. Hoje, depois de tantos anos cantando no teatro, tentando preparar diferentes vozes e coros para cantarem junto, 
conhecer um pouco mais a própria voz, ter boas noções de ritmo, de harmonia, só posso chegar à conclusão de que a prática é o segredo. E que cada caso é um caso. Cantar junto cada vez mais para que o cantar junto fique bom para quem veio ouvir. Não tem milagre. Um ou outro gênio da música pode aparecer, e isso é sempre bem-vindo. Apenas pela presença, ele é capaz de elevar o nível musical do grupo inteiro. Ao mesmo tempo, pode ser que ele não consiga cantar em coro, que não tenha paciência de ensaiar com todos, que sua voz sobressaia demais, o que por outro lado interfere numa possível maior dificuldade de timbragem do grupo.

Ou seja, são muitas nuances, muitos detalhes. Só trabalhando grupo a grupo. Praticando. Só mesmo cantando para saber.

Voltando aos deuses, Zé Celso vê, ouve, cria e interpreta a música dionisiacamente. Ator experiente que é, usa a música com desenvoltura e com ela amplia os sentidos do texto. Compõe música tendo a intenção do texto e da interpretação como guias e sabe interpretar cantando, aproveitando nuances, improvisando dentro da harmonia. Livre. Briga com Apolo se nos atemos ao ritmo. Apesar de sempre valorizar o coro, o ator Zé integra-se com dificuldade ao coro cantante porque não ouve a música pelo ritmo. Ouve muito mais a harmonia, e nela navega livremente, criando facilmente melodias de improviso. Mas derruba primeiro o percussionista e em seguida a banda toda, que acaba tendo que acompanhá-lo no ritmo só dele, que canta no ritmo da cena.

Como se isso não bastasse, para confundir um pouco mais:

O aprofundamento da separação entre a música apolínea e a dionisíaca a favor da primeira provocará, com o tempo, a estabilização de uma hierarquia em que, assim como a música se subordina à palavra, o ritmo se subordina à harmonia (já que o ritmo equilibrado é aquele que obedece a proporções harmônicas em detrimento dos excessos rítmicos, melódicos e instrumentais da festa popular). Pode-se dizer, considerando a concepção harmônica do ritmo, tal como vigora em Platão, que este, por si só, não dá logos (assim como se diria, por outro lado, que o logos não dá samba) (WISNIK, 1989, p. 104, grifo do autor).

Então agora virou tudo ao contrário, o ritmo é apolíneo, e estamos cantando acompanhados por uma banda que usa instrumentos temperados, com canções compostas segundo uma lógica (!) da música como a entendemos hoje. 
Não pretendo me aprofundar nos aspectos apolíneos ou dionisíacos segundo este ou aquele autor, de Nietzsche a Schafer, passando por nosso parceiro compositor José Miguel Wisnik. Não será na definição do que é apolíneo ou dionisíaco que encontraremos o caminho. Nossa questão encontrará respostas na prática.

Melhor então falar da nossa prática diária e da briga que temos entre a turma do ritmo e a da harmonia, dos afinados contra os desafinados pensando na harmonia como a entendemos e praticamos hoje e no acompanhamento de uma banda -, dos que cantam em coro e dos que preferem solar sempre - aqueles que preferem sentir que sua voz se destaca, seja pelo timbre, pelo volume, pela intensidade ou pelos truques de prolongar as frases para além de todos, de exagerar no vibrato e outras travessuras mais de integrantes do coro que não apreciam tanto as delícias do trabalho coletivo e a sensação de se perder no coro sem órgãos.

Procurei nos conceitos de dionisíaco e de apolíneo explicações para nossos conflitos no teatro em relação ao coro, à nossa preparação para o canto. Relacionamos o teatro a Dionísio; o Oficina é conhecido pela sua abordagem dionisíaca não só do teatro, mas também da vida. O apolíneo estaria relacionado à música em seu sentido matemático, por isso o ritmo é tido como de característica apolínea. Isso já me confunde em relação à minha própria percepção, pois sempre senti o ritmo, a repetição, a vibração dos tambores - ou mesmo o ritmo da fala ou o implícito na música sem base instrumental rítmica como responsável por nos levar a um estado alterado, muito importante para possibilitar que o coro consiga cantar junto e pulsar numa mesma vibração, mas, para além disso, num estado para além do racional, um estado de compreensão em um nível mais sutil. Uma pulsação comum que nos possibilite uma comunicação pelo movimento, pelo olhar, por uma energia comum que se forma, um fenômeno físico, invisível para nossos sentidos comuns, mas, pela prática constante, quase visível ou tocável pela intensidade da presença. Percebia que depois de um tempo dançando e cantando juntos - ou mesmo falando a partir de um ritmo marcado, um ritmo comum a todos, alcançávamos um estado de coro, uma compreensão e uma comunicação além da racional.

Quanto mais utilizávamos ritmos mais quebrados e que proporcionavam uma dança mais solta, de corpo inteiro, mais livres de condicionamentos 
ficávamos e mais nos predispúnhamos a diferentes e novas interpretações. Outra prática que nos deixava disponíveis e mais abertos a sair de nossos papéis cotidianos, era cantar e cantar e cantar. Juntos, durante uma hora ou mais, em roda, ligados na e pela música. Às vezes cantávamos uma mesma canção repetidamente, quando no levantamento de alguma cena, ou apenas para chegarmos a uma compreensão da música no tocante a sua melodia e harmonia ou da interpretação exigida pela cena. Essa prática nos coloca num estado de prontidão não apenas em relação à música - a possíveis improvisações, criações de novas melodias, novos encaixes de letra e música -, mas também em um estado de prontidão para a compreensão dos sentidos do texto.

A música é uma linguagem, assim como a escrita ou a linguagem dos signos, as imagens. Aprender a melodia de uma canção é como decorar um texto. Para aprender uma melodia, você entra numa outra sintonia, a sintonia da música, abre os ouvidos, percebe o som, sente no corpo como emitir a voz para repetir aquele som, percebe onde o corpo vibra, sente onde a voz é formada, que movimento o corpo faz para emitir aquele som. Sem muita racionalidade, é físico, é corporal. É uma linguagem do corpo. Com uma melodia já memorizada, é mais fácil trabalhar sentidos, entonações, compreensões e interpretações. Por que não dar o tempo devido a esse aprendizado? A essa compreensão? Por que a música tem que ser obrigatoriamente intuitiva, mesmo para alguém que não tem familiaridade com a linguagem musical? Essa sempre foi uma questão para mim durante os processos de criação no Oficina, presente nos ensaios e motivo de embates com o diretor. E, como a maioria dos embates, sinto que durante anos foi uma contracenação muito produtiva e que resultou em melhor qualidade musical do grupo. Uma busca incessante cujo objetivo era sempre valorizar a cena, chegar em sua potência máxima.

Depois de muito tempo preparando tanto o coro do Oficina como outros grupos para cantar, cheguei à conclusão de que o mais importante é mesmo cantar e, além disso, cantar junto. Os exercícios vocais são importantes para cuidar da voz, para conhecer um pouco do próprio instrumento para não o forçar e assim poder contar com ele sempre. Um aquecimento básico quando sabemos que vamos usar muito a voz é um bom começo.

Os exercícios de percepção musical são importantes para que a linguagem musical vá se tornando mais familiar ao ator. E, principalmente, para se 
preparar um coro, é importante que se chegue a um patamar comum de familiaridade dos componentes com a música. Quando percebemos um ponto fraco no coro, podemos trabalhar determinados exercícios com esse mesmo coro para resolver falhas pontuais.

Se o ponto fraco é afinação, caprichamos, por exemplo, nos vocalizes com escalas e notas longas com vogais. Se o ponto fraco é cantar junto, é preciso acertar entradas, fazer textos compreensíveis pelo encaixe das palavras na música e caprichar nos exercícios rítmicos e de articulação. Se o ponto fraco é a percepção da harmonia, podemos focar em exercícios com pequenas improvisações melódicas a partir de harmonias simples que podem ir se complexificando. E, a partir das harmonizações com divisões de vozes e dos exercícios que tornam perceptíveis os intervalos musicais que soam bem juntos, desenvolver a capacidade de ao mesmo tempo emitir um som e ouvir outro diferente que "combine" com o seu.

No entanto, o grande segredo vai ser cantar junto pelo prazer de cantar. E praticar sempre. Cantar canções que dialoguem com o grupo, que tenham algum sentido de ligação entre as pessoas, que falem diretamente ao momento presente, que ativem a imaginação.

\section{O samba como aquecimento}

... a bacanal heroica que era o Carnaval de outrora... Quando o Morro descia sobre a cidade, com seus sambas, suas inconfundíveis canções, suas baianas monumentais, seus porta-estandartes e balizas. Era a Grécia, a Grécia no seu grande sentido nietzschiano. O senhor conhece Nietzsche? É um filósofo alemão que descobriu a outra Grécia, não a de Renan e a de Bilac... A Grécia de Baco, pai do Rei Momo... (ANDRADE, 1996, p. 118) ${ }^{6}$

Praticando - e estudando - algumas técnicas de meditação na vida diária assim como em diferentes processos de criação, pude perceber resultados práticos de percepção muito significantes e traçar paralelos com nossas experimentações com a música no teatro. Sem me alongar nesse assunto, que merece estudos aprofundados, quero apenas salientar que, por exemplo,

6 Oswald de Andrade em crônica publicada pela primeira vez em 2 de março de 1944, para a seção "Telefonema" do jornal carioca Correio da Manhã. 
com a meditação, ao atingir um estado mais profundo de consciência, temos condições de perceber sentimentos, emoções, acontecimentos e imagens com um certo distanciamento, "como eles realmente são", o que possibilita não nos identificarmos com eles - quase um distanciamento brechtiano, só que aplicado a nós mesmos enquanto personagens da vida. E com a capacidade de vê-los sem paixão e sem identificação, podemos analisá-los, entender de onde vêm, quais são suas causas e, se necessário, ou se esse for o objetivo, nos livrarmos deles. Não fugindo, evitando ou negando, mas reconhecendo, olhando-se num espelho muitas vezes nada favorável e, a partir do que vemos, decidirmos então o que fazer.

A religião e a arte (e também a filosofia metafísica) se esforçam em produzir a mudança da sensibilidade, em parte alterando nosso juízo sobre os acontecimentos (por exemplo, com ajuda da frase: "Deus castiga a quem ama"), em parte despertando prazer na dor, na emoção mesma (ponto de partida da arte trágica) (NIETZSCHE, 2005b, p.79).

O samba traz em si essa sabedoria. Para além do ditado sempre lembrado, "quem canta os males espanta", que já é uma bênção muito concreta, o samba tem em comum esse passo a mais, central para o paralelo que faço com a técnica de meditação e que passa pela visão: olha-se para as emoções, para os sentimentos, mas a partir de um estado de consciência alterado, mais profundo, o estado que alcançamos quando estamos cantando. É como se puséssemos um holofote naquele sentimento que mais queremos esconder ou simplesmente fingir que não existe.

Muitas vezes compostos em tons menores, o que em senso comum implicaria em estímulo para estados melancólicos da alma, os sambas estimulam um cantar vigoroso e com tônus no corpo inteiro devido ao seu ritmo sincopado. Temos muitos exemplos de sambas que relatam dores profundas, acontecimentos trágicos, que cantamos como um ritual de cura, como se estivéssemos indo a fundo na dor para então ultrapassá-la. "Reconhece a queda e não desanima, levanta, sacode a poeira e dá a volta por cima..., como diz o samba do compositor e zoólogo paulista Paulo Vanzolini. Choramos bastante, e então rimos de nós mesmos, de nossa condição patética de seres humanos tomados por paixões perturbadoras e que nos levam ao fundo do poço do 
sofrimento da miséria humana. Nos reconhecemos nessas misérias, cantamos o bode, rimos de nós mesmos, e assim nos curamos, nos libertamos de dores que nem nos pertencem, das dores do mundo. "Como um samba deve ser, pra cantar a noite inteira e se curar no amanhecer," diz a letra do samba Só eu só, que escrevi à margem de um texto de alguma peça que ensaiava no Oficina e que depois musicamos juntos, meus parceiros de Revista do Samba7 e eu, num ensaio ali mesmo no teatro [\#Só eu só].

Cantar sambas foi parte de nosso aquecimento de voz durante anos no Teatro Oficina. Me lembro das primeiras vezes em que atuei junto ao grupo, no espetáculo Bacantes, e só o que cantávamos antes de entrar em cena, para mim, já era suficiente para me dar vontade de estar ali. Sambas de Jackson do Pandeiro, Edgar Ferreira, Noel Rosa, Assis Valente, sucessos de Carmen Miranda, Isaurinha Garcia, Trio de Ouro, e as marchinhas de carnaval mais debochadas, em honra a Dionísio... Cantávamos uns para os outros, interpretando e brincando com as letras, contracenando com um mesmo texto que ia e vinha, ar que passava de boca em boca, pulmão em pulmão, palavras que contavam histórias, provocavam, faziam confissões, que cantávamos juntos e em pequenos diálogos provocativos. Canções de duplo sentido, muitas hoje banidas de muitos repertórios pela carga preconceituosa das letras, mas cantadas ali viradas ao avesso, tabu em totem, ressignificando possíveis xingamentos, transformados em exaltação: "olha a cabeleira do Zezé, será que ele é, será que ele é...bicha!!”, e outras, com muito orgulho.

Além do aquecimento da voz, da afinação, da timbragem e do entrosamento, com o samba desenvolvemos uma percepção rítmica de coro muito além do básico na música. Pelo sincopado do samba, pela marcação no contratempo, desenvolvemos uma esperteza rítmica na voz, no encaixe das palavras na melodia, no cantar junto, que da voz ia para o corpo todo, ou do corpo que sambava para a voz, deixando o coro num estado de prontidão e fazendo vibrar todos numa mesma pulsação requebrada. Cantando em roda, um vendo o outro, dançando junto, rebolando, e mantendo a roda - na pista do Oficina mais para ovo do que roda -, uma distância equilibrada entre um

7 O violonista Beto Bianchi e o percussionista Vítor da Trindade, ambos também compositores e meus parceiros no trio Revista do Samba. Para mais informações, cf.: http://bit.ly/3pLJZi2

8 Marchinha de João Roberto Kelly e Robert Faissol, sucesso do Carnaval carioca de 1963. 
e outro, sem buracos, sem quebra de fluxo, no ritmo da roda. $E$ as letras dos sambas, verdadeiros tratados de filosofia, psicologia, sociologia, que preparavam o ator atleta afetivo para atuar em coro na tragicomediorgia.

"Sambar é chorar de alegria é sorrir de nostalgia dentro da melodia..." A prática constante do samba - seja nos aquecimentos vocais diários anteriores aos ensaios, seja como preparação para entrar em cena com os espetáculos em temporada -, atua ampliando a percepção musical dos atuadores, observada no aumento de possibilidades rítmicas da fala e em uma maior organicidade entre a fala e os movimentos e gingados do corpo. E, em um nível mais inconsciente, traz toda uma tradição ligada à gênese do gênero musical que, além de marcante característica festiva e da forte religiosidade, traz em seu cerne a tragédia da diáspora de diferentes povos africanos arrancados de seu lugar de origem e transportados para serem escravizados além-mar. Melodias e ritmos africanos misturados às muitas misturas que se operaram ao longo dos anos de colonização das terras de Pindorama, de diferentes povos originários às diversas musicalidades de invasores europeus. Cantos de trabalho, cantos de lamento, de saudade, de dor, de alegria. "Tire o seu sorriso do caminho, que eu quero passar com a minha dor", canta Nelson Cavaquinho em sua parceria com Guilherme de Brito. Uma tradição que se faz presente também na dramaturgia do Oficina, com trechos de sambas misturados às palavras de Euclides da Cunha, Eurípedes, Oswald de Andrade e tantos outros poetas dramaturgos levados à pista.

E o jeito de interpretar as letras dos sambas, com influências de cantores diversos, cantos meio-falados, degustando as palavras, interpretando os sentidos, deixando subtextos e duplos sentidos abertos à imaginação dos ouvintes. Tudo isso somado, e praticado incansavelmente no Oficina, resultou em interpretações únicas, fortes, musicais, ritmadas e de conteúdo trágico mesmo na alegria. "A felicidade do povo é uma felicidade guerreira", já dizia Oswald de Andrade "de 1929 para trás", no livro Serafim Ponte Grande (2007, p.). "A alegria é a prova dos nove", disse também na mesma época, no “Manifesto Antropófago", de 1928.

9 Trecho do samba Feitio de Oração, música de Vadico para letra de Noel Rosa, de 1933. 
Daí minha conclusão depois de anos criando, cantando e sambando no Teatro Oficina, de que a maior contribuição minha ao coro do teatro foi ter incorporado e fortalecido oficialmente o samba aos aquecimentos de voz e às apresentações diversas, na maioria das vezes acompanhada por meu cavaquinho, um instrumento harmônico e rítmico, fácil de carregar pela pista do teatro e pelas pistas das ruas das cidades. Para estimular uma afinação das vozes para além das harmonias conhecidas: uma afinação da voz com o corpo, dos corpos com o ritmo, afinação da alma e da mente com a tragédia, o cenário sonoro para a catarse, e "a transformação permanente do tabu em totem", mais uma vez como disse Oswald de Andrade em seu "Manifesto Antropófago" (2001, p. 69). O samba, em seu ritmo, suas melodias, suas interpretações, seus conteúdos e suas requebradas opera em grau máximo para colocar o coro de prontidão também para o prazer, fator determinante para a sedução do público, que no Teatro Oficina é constantemente convidado a ultrapassar o papel de simples espectador para a assumir o de atuador. Assim como a música, para além de decolonizada, é a própria decolonização incorporada. Com muita ginga.

\section{Referências bibliográficas}

ANDRADE, O. Telefonema. São Paulo: Globo, 1996.

ANDRADE, O. A utopia antropofágica. 3a. ed. São Paulo: Globo, 2001.

ANDRADE, O. Serafim Ponte Grande. São Paulo: Globo, 2007.

NIETZSCHE, F. A visão dionisíaca do mundo, e outros textos de juventude.

Tradução: Marcos Sinésio Pereira Fernandes, Maria Cristina dos Santos de Souza. São Paulo: Martins Fontes, 2005a.

NIETZSCHE, F. Humano, demasiado humano: um livro para espíritos livres.

Tradução, notas e posfácio: Paulo César de Souza. São Paulo: Companhia das Letras, 2005b.

NIETZSCHE, F. O nascimento da tragédia ou helenismo e pessimismo. Tradução, notas e posfácio: J. Guinsburg. São Paulo: Companhia das Letras, 2007.

SCHAFER, M. The soundscape: our sonic environment and the tuning of the world.

Rochester: Destiny Books, 1994.

WISNIK, J. M. O som e o sentido. São Paulo: Companhia das Letras, 1989. 
